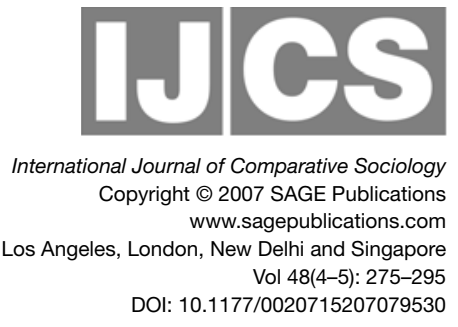

\title{
World Society, NGOs and Environmental Policy Reform in Asia
}

\author{
David John Frank \\ University of California, Irvine, USA \\ Wesley Longhofer and Evan Schofer \\ University of Minnesota, USA
}

\begin{abstract}
We examine the role of domestic nongovernmental organizations (NGOs) in environmental policy reform in Asia. Standard accounts treat NGOs as critical players in the policy process, responding to local environmental degradation and pressing states for environmental reforms. We argue, by contrast, that environmental policy changes are borne largely of the global environmental regime, and that domestic environmental NGOs in Asia are better seen as products of world society than as independent actors driving policy change. Both qualitative and quantitative analyses support our view. In event-history analyses of policy reform, we find that both ties to world society and linkages to the global environmental regime are stronger predictors of policy adoption rates than domestic environmental NGOs or local degradation. We suggest that the rhetorical centrality of 'grassroots' NGOs results not from any direct impact such associations have on political change but rather from their roles in the theater of democracy, which is staged in a post-Second World War liberal world culture that celebrates bottom-up voluntary organizing and participation, even when such associational activity is only loosely connected to domestic political change.
\end{abstract}

Key words: Asia $\bullet$ environment $\bullet$ globalization $\bullet$ NGOs $\bullet$ policy $\bullet$ reform

In the social sciences, it is commonplace to assert that grassroots social movement organizations play key roles in catalyzing national policy reforms. The core idea is a bottom-up functionalist one, in which domestic nongovernmental organizations advocate 'the needs and demands of civil society' such that 'policy reform initiatives' emerge from 'local civil society organizations' and 'social and grassroots movements. ${ }^{1}$ While this causal imagery is only recently minted and largely western in origins, it is nevertheless often presumed to hold true generally worldwide. A growing body of research probes the NGO policy tie skeptically, but most of this work is limited in scope, focusing on changes in the United States 
or other developed western democracies. In this article, we reconsider the central issues in comparative perspective, investigating in particular what impact domestic environmental NGOs have had on recent environmental policy reforms in Asia. Several of the literature's prevailing conventions, it turns out, must be recalibrated to fit the new context.

\section{BACKGROUND}

By all accounts, environmental degradation in Asia is extreme. Almost all of the region's high-growth economies have followed a grow-first-and-clean-up-later development strategy. ${ }^{2}$ The result, according to the Asian Development Bank, is that Asia is now the dirtiest continent on Earth (Rock and Angel, 2005). Along with widespread and severe air and water pollution, a host of more specific problems beset the region. Deforestation, for one, is rampant. With 10 percent of the world's rainforests, for example, Indonesia loses as much as one million hectares of forest every year (Gordon, 1998). Likewise the loss of biodiversity is extensive. A recent survey in China, for instance, showed that between 20 and 40 percent of that country's species are threatened, with almost one falling extinct daily. ${ }^{3}$ The gravity of Asia's environmental degradation has intensified over recent decades (Sonnenfeld and Mol, 2006).

Even as this has occurred, environmental social-movement activities have sprung up around the region, taking off generally in the 1970s. Thus by 1990, for instance, the South Korean Federation Environmental Movement provided umbrella services to about 200 environmental NGOs. ${ }^{4}$ Environmental movement activities appeared somewhat earlier in Japan, in the immediate aftermath of the Second World War (Broadbent, 1998). And in China, activities to protect the environment began relatively late:

Since 1994 and the founding of the first environmental NGO in China, Friends of Nature, there has been a spectacular increase in both the number of environmental NGOs in China and in the range of activities they undertake. Environmental NGOs have evolved from organizations devoted almost exclusively to environmental education and biodiversity protection to those willing to criticize the government openly..${ }^{5}$

Now in virtually every Asian country, there is a long list of domestic environmental NGOs - entities that range in size and permanence from tiny fledgling grassroots coalitions to longer established, better funded, and technically sophisticated formal organizations (Jasanoff, 1997). ${ }^{6}$

Concomitant with the rise of NGOs, waves of environmental regulatory reform have swept through the Asian region. Some such waves have carried very general guidelines for environmental protection, such as impact assessment laws, which require analyzing the environmental impacts of proposed construction projects in order to minimize their damaging effects (Hironaka and Schofer, 2002). Other reform waves have brought narrower regulatory changes, such as those restricting the use of chlorine in the pulp and paper industry (Sonnenfeld, 2002). With 
the embrace of such policies, nation-states in the region have embarked on the broad road of environmentalization (Frank et al., 2000a).

At least a few of these initiatives have achieved notable success. In Malaysia, for example, the palm oil production process has been effectively stripped of polluting effluents (Rock and Angel, 2005). In Nepal, meanwhile, the number of critically endangered one-horned rhinoceroses has quintupled in the quarter century since conservation efforts began in $1972 .{ }^{7}$ While undoubtedly more exception than the rule, similar environmental success stories can be found in many Asian countries.

Analytically, of course, the crucial question to be asked is how all these factors interrelate. What, if any, are the causal connections between the onset of serious environmental degradation, the proliferation of domestic environmental NGOs, the multiplication of national environmental policy reforms, and ultimately environmental clean-up?

In prevailing popular and scholarly accounts, the answer is seemingly clear. The basic imagery is straightforward and linear. Environmental ills spur the formation of domestic NGOs, which in turn propel national policy transformations, which finally generate environmental ameliorations. We illustrate this view in Figure 1.

At first glance, the causal relationships delineated in Figure 1 seem to make sense, in part because they align so squarely with functionalist ideologies and democratic ideals that are deeply institutionalized in western contexts. Regardless, the scheme encounters serious difficulties when assessed in systematic empirical terms.

A first difficulty appears vis-à-vis the initial causal arrow from local environmental degradation to domestic NGO formation. History offers striking evidence that even the most devastating environmental problems only exceptionally mobilize public awareness or spur organizational formation. Much more typically, people ignore foreboding signs and suffer the consequences accordingly (as the tolls from many predictable - and predicted - natural disasters poignantly illustrate). Furthermore were local degradation in fact a fundamental catalyst to peoples' actions and perceptions, one might expect to find cross-national variation in environmental values, given highly variable states of degradation. On the contrary, however, environmental values are remarkably homogeneous worldwide. People in all sorts of countries - rich and poor, Christian and Confucian, degraded and non-degraded, etc. - value more or less the same types of environmental protection at more or less the same levels (Brechin and Kempton, 1994; Dunlap and Mertig, 1997). Further doubts about the degradation-mobilization tie arise from quantitative analyses of aggregated cross-national data. Neither a limited sample of non-western countries

Figure 1 Conventional depiction of the NGO-policy relationship

\begin{tabular}{|c|c|c|c|}
\hline $\begin{array}{l}\text { local environmental } \\
\text { degradation }\end{array}$ & $\rightarrow \mid \begin{array}{l}\text { grassroots domestic } \\
\text { environmental NGOs }\end{array}$ & $\begin{array}{l}\text { national policy } \\
\text { reforms }\end{array}$ & $\begin{array}{l}\text { environmental } \\
\text { cleanup }\end{array}$ \\
\hline
\end{tabular}


(Longhofer and Schofer, 2006) nor a broad sample of countries worldwide (Frank et al.,2000b) suggests any systematic relationship between natural degradation and environmental NGO formation. Indeed, it appears that the world's most despoiled countries typically have the weakest grassroots environmental movements, while the most pristine countries have the strongest. In these lights, the degradation-tomobilization connection appears tenuous at best.

Similar difficulties beset the putative tie from national environmental reforms to environmental cleanup, at the end of the chain in Figure 1. Many analysts have demonstrated that this relationship is loosely coupled or altogether decoupled in the environmental realm - with deficits of political will, scientific know-how, and economic capacity posing just a few of the barriers to effective policy implementation (Ascher, 1999; Hironaka and Schofer, 2002). In extreme cases, the very officials charged with environmental protection profit from its exploitation, as when Cambodia's prime ministers and armed forces presided over illegal timbering, causing severe ecological damage. ${ }^{8}$ More commonly, good-faith efforts by government agents are simply overwhelmed by the complexities of environmental problems and countervailing demands from local constituencies. The important point here is that the ameliorating effects of policy reforms on environmental outcomes - assumed in Figure 1 - are in fact highly conditional, strongest, perhaps, when new regulations are '1) highly structured; 2) when they penetrate actors at multiple levels of the social system; and 3) when they are persistent over time' (Schofer and Hironaka, 2005: 25).

These doubts concerning the first and third causal connections depicted in Figure 1 lead us to wonder about the middle linkage, tying domestic environmental NGOs to national policy changes. Beyond a handful of case studies, from which generalizations are impossible, this middle causal relationship has largely escaped academic scrutiny. Accordingly in what follows, the NGO policy connection is our primary object of analysis.

\section{DOMESTIC NGOS AND POLICY REFORMS IN CONVENTIONAL PERSPECTIVE}

Direct and systematic assessments of the NGO-to-reform linkage are rare in the extant literature, no doubt in part because the catalyzing effects of domestic NGOs on policy changes are sacred cows. From most analytical purchases, it is unquestioningly assumed that NGOs convey grassroots social movement demands to state officials and thus impel policy reforms. Belief in this process is sufficiently deep that even absent empirical support on the matter the UN Environment Program can blithely declare that:

NGOs have emerged as major partners in development and conservation activities ... [They] have helped design and implement environment policies, programs, and action plans, and set out specifications for EIAs [environmental impact assessments]. They also play crucial advocacy roles. ${ }^{9}$

It seems by fiat more than by evidence, observers have asserted a causal tie from domestic environmental NGOs to national regulatory reforms. 
Of course, domestic NGOs themselves are members of the chorus espousing such views. To wit, the Seoul Declaration on the Cooperation of Environmental NGOs vows that NGOs will help the countries in the region, particularly those that are less developed, to build 'appropriate infrastructure and technologies' to solve 'urgent environmental problems. ${ }^{\text {'10 }}$ Consistent with this mission, to illustrate, the Japanese NGO Mekong Watch - established in 1993 to monitor the social and environmental impacts of regional development initiatives - maintains that:

NGOs have been highlighting the problems of Japanese ODA [official development assistance] and making inroads in policy recommendations. Communities and NGOs in the Mekong Region are also growing stronger in demanding their right to maintain their traditional livelihoods and protect the integrity of their environments. The Japanese government has had to begin more seriously re-examining many of its policies. ${ }^{11}$

Similar claims of NGO influence can be heard from grassroots environmental associations dispersed throughout the Asian territories.

From the other side, Asian policymakers likewise advocate the notion that domestic environmental NGOs provide crucial sparks to national regulatory reforms. Thus for instance in 2001, the Prime Minister of Cambodia praised the local NGO Forum for supporting fisheries reform and requested the Forum's help in organizing future community consultations on a newly drafted fisheries decree. ${ }^{12}$ In the same vein, Indonesia's Assistant Minister for the Environment declared that increasing NGO pressure compelled the Environmental Control Agency to cite hundreds of companies for pollution violations (Gordon, 1998), while Japan's Prime Minister announced that NGO initiatives were indispensable in promoting environmental conservation in the country. ${ }^{13}$ From both sides, then, participants avow a causal relationship from domestic environmental NGOs to national regulatory reforms.

Academic interest in environmental NGOs and environmental policies has exploded in recent years (e.g. Bryant, 2005; Sonnenfeld, 2002; Sonnenfeld and Mol, 2006; Wong, 2001), yet few scholars have questioned the core assumption that domestic NGOs exert decisive sway over environmental policy changes. This has remained true even as some analysts have admitted that hard evidence of NGO influence has been difficult to isolate (Potter, 1996). In many studies, NGO activities, access, and/or resources have been treated as proxies for causal relevance - not because their influence is observable but because they are present on the scene. Despite such empirical shortcomings, one review of the literature still insists that a 'growing body of evidence indicates that NGOs influence government decisions to develop domestic policies to protect natural resources' (Betsill and Corell, 2001: 65).

All in all, one finds a common belief among scholars, national policymakers, and domestic NGO leaders that grassroots environmental NGOs play decisive roles in promoting national policy reforms, channeling the voices of local peoples into organized political demands. In the remainder of this article, we present arguments and empirical data that challenge this consensus - reconsidering the origins 
of domestic NGOs and national regulatory reforms and also the interrelationship between the two.

\section{CHALLENGES TO THE CONVENTIONAL PERSPECTIVE}

Standard accounts of the environmentalization process in Asia are rhetorically compelling, but there are nevertheless logical and empirical reasons to reconsider them. The NGO-to-reform orthodoxy, we argue, ignores an important dimension of change in the environmental arena, allowing it to exaggerate the impacts of secondary forces.

To begin, there are obvious questions regarding NGO effectiveness. Conventional analyses of regulatory reform problematically assume that Asia's domestic environmental NGOs can reasonably be said to effectively translate grassroots collective interests into meaningful demands for regulatory change. While the effectiveness assumption draws heavily on dominant western ideals (carried, for instance, by much social movements scholarship), even the most rudimentary field observations question its validity. To an overwhelming extent, Asia's domestic environmental NGOs are new, small, and poorly funded. Even in prosperous and democratic Japan, a ministerial survey found that nearly half of 386 environmental NGOs did not have a single paid full-time staff person. ${ }^{14}$ Outside of Japan, the situation is presumably worse. (Indeed, it is precisely because of their weaknesses that 'capacity building' is so prominent among domestic NGO priorities. ${ }^{15}$ ) Given resource constraints, operational hamstrings, and the fragility of NGO coalitions, it is difficult to see how domestic NGOs could operate as effective pressure groups in Asian countries, leveraging policy reforms (cf. Carr and Mpande, 1996, on the African context). Of course, organizational efficacy is difficult to assess (Bestill and Corell, 2001). Still the literature shows that even those most inclined to finding NGO influence on state environmental policies often come up empty-handed (Potter, 1996).

Beyond doubts about NGO effectiveness are questions about NGO autonomy. The standard accounts summarized in Figure 1 hinge on the assumption that domestic environmental NGOs in Asia can be meaningfully construed as indifferent to and independent of external social forces - be those forces INGOs, IGOs, transnational corporations, or nation-states. This assumption is central because autonomy is the anchor of NGO integrity. To represent local interests authentically, domestic environmental NGOs must arise directly from the grassroots, in response to local environmental ills. Otherwise NGOs (unelected and unaccountable, after all) may simply represent handmaidens of the elite or particular societal interests, especially when NGO resources run short. The plausibility of the autonomy assumption, like the effectiveness assumption, relies on deep western biases. But again there are reasons to be skeptical.

First, NGOs depend heavily on their host nation-states. In China, to take an extreme case, the NGO terminology is sufficiently misleading in regards to 
autonomy that many scholars insist on the alternative designation GONGOs governmentally organized non-governmental organizations. China's administrative reforms of 1998 'triggered a boom in the number of GONGOs,' established 'primarily in order to receive international assistance' and 'to strengthen technology and information support' for the state (Wu, 2003: 36). Even if GONGOs were to gain degrees of independence over time, it remains the case that the causal imagery depicted in Figure 1 - from NGOs to policy reform - is misleading if NGOs are direct spin-offs from the nation-state. Similar doubts about NGO autonomy arise in Vietnam, where 'under relatively rigid state control, the few NGOs that exist are little more than training and advisory groups focusing on environmental impact assessment.' The interpenetration is so great that 'it is difficult to draw the line' between the governmental and nongovernmental domains in Vietnam (Pednekar, 1995: 22). Of course, in most Asian countries, the dependence of NGOs on the state is somewhat lower than it is in China or Vietnam. Still even in the most democratic of national settings, autonomy from the state is rarely more than partial. ${ }^{16}$

Similar qualifications apply in regards to domestic NGO autonomy from international organizations, both governmental and nongovernmental. International organizations often provide vital financial support to NGOs and their activities. Sri Lanka's Centre for Environmental Justice, for example, originated in 2004 with financial support from Community Aid Abroad (Australia), Both Ends (Netherlands), Environmental Defense (US), NGO Forum on Asian Development Bank (Philippines), Global Greengrants (US), Institute of Professional Environmental Practice (US), Environmental Law Alliance (US), and the Korean Federation for Environmental Movement (South Korea), among others. ${ }^{17}$ Furthermore, international organizations often provide informational and strategic resources for example, 'activist toolkits' with how-to instructions on everything from NGO formation to NGO influence. For instance, the Bank Information Center (US) offers a toolkit that helps 'local groups learn the leverage points of the MDBs [multilateral development banks], become aware of MDB policies that protect the environment and vulnerable populations, and gain access to basic information about planned projects. ${ }^{18}$ The global diffusion of strategies, guidelines, and other forms of information produces a level of isomorphism among the NGOs of different countries that seems to belie the conceit of NGO independence. In short, ties between international organizations and domestic NGOs appear to be pervasive, and while such ties may increase NGO effectiveness, they violate the myth that domestic environmental NGOs are bottom-up, grassroots, peoples' associations, autonomously representing the interests of local peoples. ${ }^{19}$

In many historical accounts of environmental policy change, domestic NGOs appear to be neither effective nor autonomous. For example, during the 1980s and 1990s:

communities in Australia and Southwest Asia were faced with very large scale proposed rural development projects in the form of pulp and paper mills combined with the 
establishment of extensive plantations. Such projects, with estimated price tags of half a billion US dollars or more, were high-profile, top-down affairs. Communities struggled to have a voice in decision-making regarding the projects themselves or their attendant social and environmental impacts ... Greenpeace's global campaign against chlorine in pulp and paper manufacturing came at an opportune time for community activists. (Sonnenfeld, 2002: 9)

In this case - as in many others - domestic environmental NGOs gained leverage only after INGO intervention (here, by Global Greenpeace). In sum, the causal tie imputed by standard accounts between domestic NGOs and environmental policy reforms falters both on effectiveness and autonomy grounds.

\section{THE PRIORITY OF WORLD SOCIETY}

If not via the conventional storyline, then, by what processes do environmental NGOs and national environmental policies originate, and what is the relationship between the two? In contrast to the dominant literature, we propose that domestic environmental NGOs and national policy reforms both derive from world society (Meyer et al., 1997a), flowing out from the ever-growing numbers of international environmental treaties, international non-governmental organizations (INGOs), and intergovernmental organizations (IGOs) that form the bases of the world environmental regime (Meyer et al., 1997b). From these common global wellsprings, domestic environmental NGOs and national policy guidelines arise and diffuse out to nation-states and national societies - those both in Asia and elsewhere.

The first proposition of this argument is that the origins of domestic environmental NGOs are not local but global. The rise of domestic environmental NGOs in Cambodia, for instance, took place during the early 1990s, when the UN Transitional Authority was administering the country. The UN's presence opened Cambodia to an influx of environmental INGOs (Pednekar, 1995), which in turn spawned domestic NGOs.

Our second proposition is similar. We argue that national environmental policies also originate in world rather than domestic society. The two major waves of environmental ministry foundings, for example, were spurred not by transformations within nation-states but instead on the occasion of the UN's two environment conferences - in Stockholm 1972 and in Rio in $1992 .{ }^{20}$ Of course, the internal characteristics of nation-states - including wealth, democracy, and education - may also open enable the formation of domestic NGOs and policy reforms. ${ }^{21}$

The third proposition of our argument is that domestic environmental NGOs and national policy reforms are often loosely coupled, in time and/or in substance (Hironaka and Schofer, 2002). This means, for instance, that rather than following a tight time sequence from NGO mobilization to policy change, Asian environmental NGOs may arise conterminously with, or even follow after, regulatory reforms. For example, the Japan Center for a Sustainable Environment and Society organized in 1993, according to its own mission statement, in part to 
'monitor decision-making procedures' at the Rio Earth Summit that took place in 1992.22 In this case, loose coupling in time is rather striking. Along the substance dimension, loose coupling is evident when - as often occurs - the concerns of domestic NGOs better reflect the world's than the local nation-state's environmental priorities. This can be seen, for instance, in the extraordinary attention given to pandas by the China Wildlife Conservation Association.

The routine appearance of loose coupling does not mean that domestic environmental NGOs can never be relevant to policy change. Early on in the process, strict causality is improbable: NGOs and policies arise together, as the twin offspring of world society. But after the two are grounded, they may turn out to be mutually enabling. ${ }^{23}$ To illustrate, after the passage of Indonesia's landmark Environmental Management Act, which asserted 'the right of NGOs to act as community institutions for environmental management and development,' the number of environmental NGOs in Indonesia mushroomed (Gordon, 1998). In this case, policy change catalyzed NGO formation.

In sum, we argue that world society provides both a global nursery and a world sprinkler system - nurturing domestic NGOs and policy reforms and then distributing them throughout the nation-states of Asia. After they take root, NGOs and policy reforms may each support the other. We summarize our view in Figure 2.

\section{EXPLORATORY EVIDENCE}

As a first step toward examining the merits of our arguments systematically, we gathered data from as many Asian countries as possible on a) the founding dates and aggregate numbers of domestic environmental NGOs (California Institute of Public Affairs, 2005), b) the passage dates of two main environmental policy reforms - impact assessment laws and environmental ministries (Frank et al., 2000a), and c) the founding dates and cumulative numbers of national chapters of environmental INGOs, such as the World Wildlife Fund's Laos Country Programme (UIA, 1948-99). These data, collected from 15 Asian countries, allow explorative inquiries into our argument's main tenets. ${ }^{24}$

Figure 2 Alternative depiction of the NGO-policy relationship

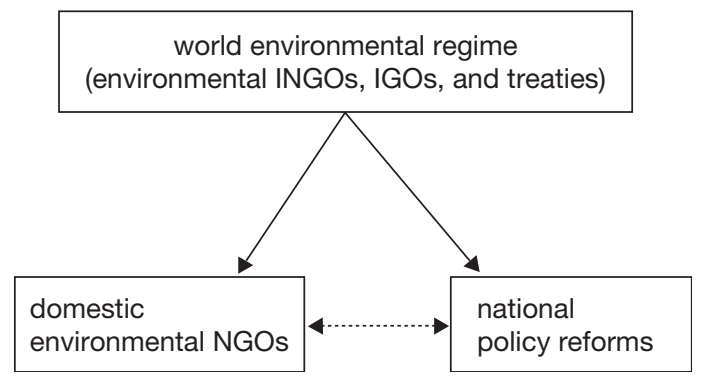


Figure 3 Cumulative sum of environmental INGO chapters and Domestic NGOs in 15 Asian countries with average founding dates of EIA law and environmental ministry, 1900-2000

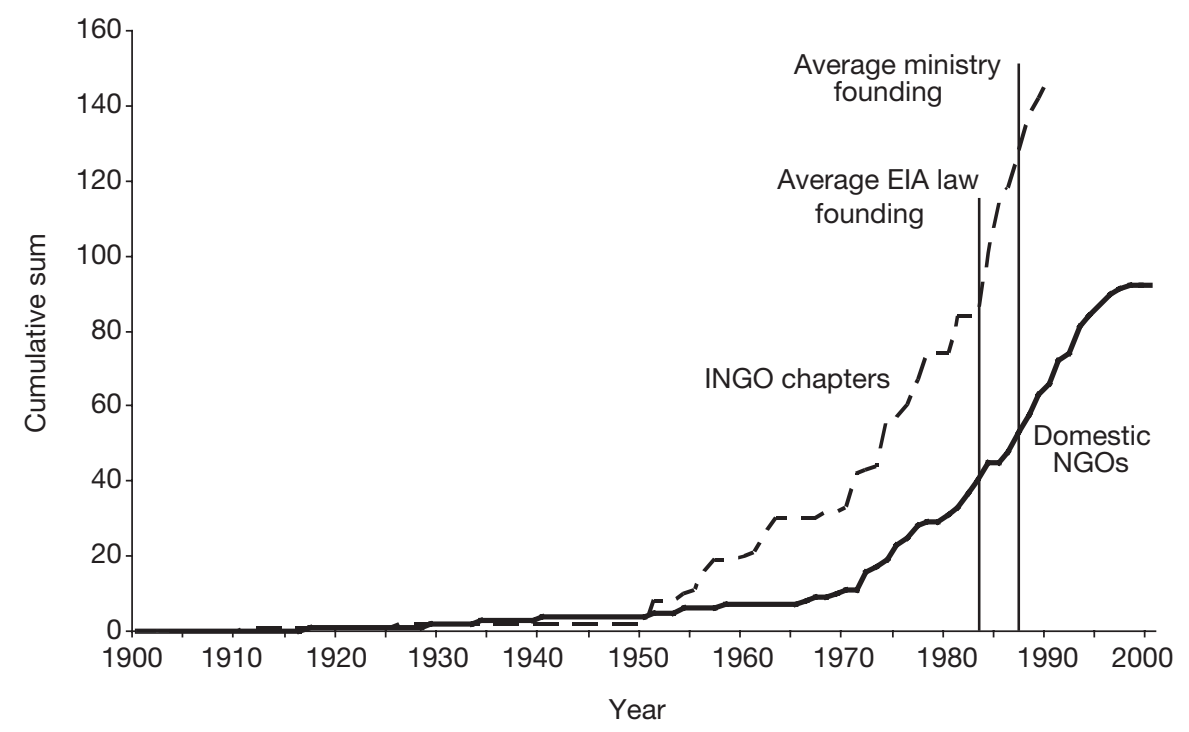

The data are summarized in Figure 3. The patterns observed there - while offering only preliminary evidence - are inconsistent with conventional accounts of the NGO-to-policy relationship, and they offer initial support for our alternative global-institutional formulation.

First, the data in Figure 3 suggest that the roots of domestic environmental NGOs lie in the soils of world rather than local society. Among the Asian countries in our sample, chapters of environmental INGOs clearly emerge first, starting to accumulate in the wake of the Second World War. Domestic NGOs follow along later, beginning to multiply only in the 1970s. This order of things implies that INGO chapters provide key ingredients for NGO formation.

Second, the chronology in Figure 3 - along with qualitative data from individual countries - is consistent with the proposition that the roots of national environmental policies lie in world rather than domestic society. Environmental policy adoptions are typically years in the making (Carr and Mpande, 1996), and on average they appear well after the number of INGO chapters has increased but more or less conjointly with the rise of domestic NGOs. Figure 3 furthermore shows that domestic environmental NGOs were few in number and recent in origin when policy reforms hit the region. Given the historical priority of INGO chapters and the fledgling quality of the domestic NGO sector, Figure 3 suggests that national environmental policies are globally rather than locally grounded.

Third and finally, the data in Figure 3 provide early support for the proposition that domestic environmental NGOs and national environmental policies - here 
measured by impact-assessment laws and environmental ministries - are only loosely coupled. While some domestic NGOs precede major policy reforms, many others post-date them. A tight causal sequence is not implied by these data.

Our initial empirical explorations, thus, lend little support to the causal evolution asserted in conventional accounts - that domestic NGOs arise first and 'cause' later policy change. Rather the data in Figure 3 offer preliminary support for the notion that domestic NGOs and national policy changes both derive from world society and the world-environmental regime, spreading throughout the Asian region in a top-down, loosely coupled manner.

\section{QUANTITATIVE ANALYSES}

We now turn to statistical tests of our arguments. Conventional accounts predict strong effects from domestic NGOs on policy changes, whereas our arguments and exploratory analyses suggest that environmental reforms come from world society, not domestic spheres. We model the adoption of national environmental policies using event-history analysis in order to determine the causal roots of reform. Event-history models are well suited to studying discrete events, such as policy adoptions, that vary in timing and may be censored. We employ a constantrate model, consistent with prior studies (e.g. Frank et al., 2000; Schofer, 2003):

$$
\mathrm{h}(\mathrm{t})=\exp \left(\beta_{0}+\beta_{\mathrm{k}} \mathrm{X}_{\mathrm{i}}\right)
$$

In a constant-rate model, $\mathrm{h}(\mathrm{t})$ represents the likelihood or 'hazard rate' of an event (in this case, an environmental policy adoption) occurring in a given year as a function of time-varying covariates. We analyze the adoption of three types of national policies: environmental impact assessment (EIA) laws; national environmental ministries; and the first comprehensive environmental law in each country (comparable to the US National Environmental Policy Act). Data on the first two variables come from previous studies (Frank et al., 2000; Hironaka, 2000). Comprehensive environmental laws are drawn from the ECOLEX website (www.ecolex.org), which documents environmental legislation for countries worldwide and is maintained by the International Union for the Conservation of Nature, the United Nations Environment Program, and the Food and Agriculture Organization. All three kinds of policy adoptions are analyzed in a common model, in order to provide a sufficient number of events for estimation. Still, our results should be interpreted with caution: the sample size is small, and several of the independent variables are highly correlated (e.g. economic development and environmental degradation).

Our time-varying independent variables include the cumulative number of domestic environmental NGOs (logged, California Institute of Public Affairs, 2005), the cumulative number of INGO chapters (logged, UIA, 1948-99), and the cumulative number of environmental INGO chapters (Frank et al., 2000). ${ }^{25}$ 
We also include controls for economic development as measured by gross domestic product per capita (logged, CICUP, 2002), population (logged, World Bank, 2001), democracy (Marshall and Jaggers, 2000), and gross enrollment in secondary educational institutions as percent of total population (World Bank, 2001). Finally, we use the 1999 'ecological footprint' to account for overall environmental degradation (logged, WWF, 2002). Although the footprint measure is not time-varying, it is one of the best measures of overall environmental damage available for a large number of countries (York et al., 2003). Our analyses cover the years 1980-2000, except in Model 3, which stops at 1990 due to missing data on environmental INGO chapters. ${ }^{26}$

\section{RESULTS}

We present the results of our event-history analyses in Table 1. Generally, the world-level variables show strong, positive effects on environmental policy adoption rates in our sample of Asian countries.

To begin, we examine the effects of domestic environmental NGOs and the five control variables - economic development, population, democracy, education, and environmental degradation - on policy adoption rates (Model 1). We find

Table 1 Event-history analysis of nation-state environmental reforms in Asia, 1980-2000

\begin{tabular}{lccc}
\hline Variables & Model 1 & Model 2 & Model 3 \\
\hline Economic development & -0.65 & $-1.45^{\star}$ & $-2.46^{\star \star}$ \\
Population & $(0.55)$ & $(0.65)$ & $(0.75)$ \\
& $-0.00^{\star \star}$ & $-0.00^{\star \star}$ & -0.00 \\
Democracy & $(0.00)$ & $(0.00)$ & $(0.00)$ \\
& 0.02 & 0.00 & 0.06 \\
Education & $(0.04)$ & $(0.04)$ & $(0.07)$ \\
& 0.01 & 0.00 & $0.04^{\star \star \star}$ \\
Environmental degradation & $(0.01)$ & $(0.01)$ & $(0.01)$ \\
& 0.07 & 0.36 & 0.56 \\
Domestic environmental NGOs & $(0.30)$ & $(0.25)$ & $(0.03)$ \\
& $0.66^{\star}$ & 0.58 & -0.73 \\
INGO chapters & $(0.30)$ & $(0.31)$ & $(0.63)$ \\
& & $1.05^{\star}$ & \\
Environmental INGO chapters & & $(0.48)$ & $1.69^{\star}$ \\
Constant & & & $(0.68)$ \\
& 1.35 & 1.24 & $11.60^{\star}$ \\
Chi-square & $(3.92)$ & $(3.38)$ & $(5.37)$ \\
Number of countries & $48.62^{\star \star \star}$ & $32.91^{\star \star *}$ & $25.55^{\star \star *}$ \\
Number of events & 14 & 14 & 12 \\
Observations & 24 & 24 & 13 \\
\hline
\end{tabular}

${ }^{\star * *} p<.001,{ }^{* *} p<.01,{ }^{*} p<.05$, two-tailed test.

Unstandardized coefficients, robust standard errors in parentheses. 
that domestic NGOs positively affect rates of pro-environmental policy adoptions, lending initial support to the conventional 'grassroots' imagery. But the model does not take into account the effects of world society, either generally or in the environmental realm. When either of these factors is added to the mix, the picture changes dramatically. The inclusion of our general world society measure - INGO chapters - reduces the size and also removes the significance of the domestic NGO effect (Model 2). Meanwhile, the INGO variable appears to have a large positive and significant effect on environmental policy adoption rates of in Asia. The pattern is even stronger in Model 3, which replaces the general INGO measure with the more specific count of environmental INGO chapters. Again, the world-level variable has a large and significant positive effect, and in this model it wipes out the impact of domestic association altogether. All in all - bearing in mind our small sample size - these results provide further evidence that the impetus for national environmental laws and ministries comes less from domestic grievances than exposure to world society and the world environmental regime.

As for the control variables, economic development and population have negative and often significant effects in all models, suggesting slower rates of policy adoption among countries facing economic and population pressures (cf. York et al., 2003). Democracy and education, by contrast, have consistently positive effects, though they are seldom significant in this small sample. The effect of environmental degradation on policy adoption rates is also positive across models, but again perhaps due to our small sample size it is statistically insignificant.

Each of the causal links in the conventional storyline - from degradation to social movements to eventual policy reform and clean-up - falters under empirical scrutiny. Like previous research on domestic NGOs (Longhofer and Schofer, 2006), we find here evidence to support the contention that national environmental policies in Asia emanate from world society's environmental regime rather than from domestic mobilization or local environmental ills.

\section{WORLD LEGITIMATION AND THE THEATER OF DEMOCRACY}

The question thus arises: if domestic NGOs and national environmental policies are both the spawn of world society, and if NGOs play at best a minor role in policy reform, how then does the conventional storyline maintain its dominance in public and scholarly discourse? How has it come to be so generally assumed that domestic NGOs can be characterized as effective and autonomous catalysts of environmental policy reform?

We offer in response three observations. The first is that regardless of any direct influence on policy, domestic NGOs nevertheless play leading roles in the global theater of democracy - in which nation-states and national citizens dramatize participatory politics on the world stage (Boli and Thomas, 1999). The cultural assumptions and organizational rules that are built into world society powerfully authorize and legitimate this form of governance, such that the very definition of the nation-state increasingly involves government by, for, and of the 
people. The script is plainly evident, for instance, in the Universal Declaration of Human Rights, adopted by the UN General Assembly in 1948. It proclaims that 'everyone has the right to freedom of peaceful assembly and association' and that 'everyone has the right to take part in the government of his country, directly or through freely chosen representatives' and finally that 'the will of the people shall be the basis of the authority of government' (Articles 21 and 22). Even highly authoritarian states such as China routinely face global (and internal) pressure to undertake democratic reforms, and while GONGOs surely differ from domestic NGOs, they nevertheless represent China's effort to perform democracy theater. The global institutionalization of democratic forms of governance lends great authority to domestic NGOs, anchoring the deference they command from nation-states, even when NGOs, in most literal senses, are nearly powerless (Schofer and Longhofer, 2006).

Within the theater of democracy, the role of NGOs is to articulate and defend the public interests - advocating for collective goods such as environmental protection (Boli and Thomas, 1999, call this 'rational voluntarism'). The privileged tax status of NGOs presumes this non-sectarian posture. The key to the NGO performance is:

gained from speaking when others will not speak, from espousing something more than narrow self-interest, from sacrificing personal gain from broader goals, from giving voice to those who otherwise do not have it, [and] from rejecting pessimism and looking for signs of hope. (Princen, 1994: 42)

In the guise of public defenders, then, domestic NGOs turn the wheels of democracy, playing high-profile roles as intermediaries between the people and the nation-state. ${ }^{27}$

In order to faithfully render the democracy drama, domestic NGOs have to be socially constructed in many countries, with building materials supplied by world society. The top-down nature of the process is especially transparent in nation-states without strong civil-society traditions, including most countries in Asia (Simon, 2006). Global templates specify what NGOs are, what they can do, and how they can interact with other entities, including nation-states and intergovernmental organizations. In Thailand, for example, the Environment Act of 1992 - passed to coincide with the United Nations Conference on Environment and Development in Rio - 'delegates the work on environmental management to provincial and local authorities and encourages people's participation through environmental NGOs. ${ }^{28}$ Meanwhile in Cambodia, National NGO Workshops sponsored by a wide variety of IGOs and INGOs - offer formal opportunities for government officials, NGO representatives, and international donor agencies all to network and interact. ${ }^{29}$ In these ways, world society enables the production of the very domestic NGOs that authenticate nation-state democracy and prove its vitality. In good part because global support is so strong, domestic NGOs have proliferated in countries around the world (Schofer and Longhofer, 2006). 
Insofar as domestic NGOs are constituted from the top-down, careful posturing is required to maintain the notion that NGOs embody independent groundswells of local mobilization, representing 'the rights of people in the civil society. ${ }^{30}$ The believability of democracy theater depends on it. Thus for instance, the INGO Environmental Defense describes its interactions with domestic NGOs in cautiously chosen terms: Environmental Defense does not create or install domestic grassroots associations but merely 'build[s] the effectiveness of local organizations.' It does not channel or dictate community interests but simply helps communities 'fight for their interests.' At the same time, Environmental Defense does not define or determine indigenous needs but only 'mobilize[s] support' to 'meet communities' needs. ${ }^{31}$ The top-down features of NGO formation are carefully veiled, to maintain the appearance of bottom-up democracy.

Even if domestic NGOs cannot be characterized as effective and autonomous catalysts of national policy reform, they nevertheless play essential roles in the theater of democracy, thus upholding conventional views of the NGO policy relationship. From this point follows a second, already suggested above, that once the theater of democracy is up and running - with whatever external supports, according to whatever globally institutionalized scripts - domestic NGOs may in fact appear to spur national policy shifts, despite their organizational weaknesses.

Typically, NGOs promote policy reforms by serving as receptor sites - receiving and transmitting signals from world society to state authorities and thus catalyzing policy adoption (see Frank and McEneaney, 1999). In Asia and the global South generally, ecological modernization has occurred as domestic NGOs have served as carriers for, 'changing global norms, ideologies, and practices of environmental regulation' (Sonnenfeld, 2002: 23). In the ongoing theater of democracy, this receptor-site role is highly consequential. NGOs offer legitimated and authorized local mouthpieces for global reforms - enacting bottom-up democracy and thus speeding the adoption of reform. Higher densities of domestic environmental NGOs increase the likelihood that global-reform signals are picked up and carried out by domestic political actors.

In cases where national political actors are resistant, domestic NGOs can sometimes implement changes directly, sidestepping the official policy process and acting under the authority of the world polity without the state's imprimatur. For example in the Philippines, a consortium of 17 environmental NGOs (NGOs for Protected Areas, Inc.) used a US\$27 million grant to operate a sevenyear Protected Areas Program - collaborating with but remaining independent of the Philippines national government. ${ }^{32}$ In these cases, domestic NGOs play not emissaries of world society but also local enforcers.

Our third main point - also already suggested - is that domestic NGOs accomplish all this with authority rather than power. As stated, most NGOs have little or no power. They are too new, too small, too poorly funded, and too seldom 
formed into coalitions to inspire much fear in the hearts of government officials. In reference to INGOs, Boli and Thomas (1999:37) note that:

INGOs cannot dominate in the conventional sense. They have little sanctioning power, yet they act as if they were authorized in the strongest possible terms. They make rules and expect them to be followed; they plead their views with states or TNCs [transnational corporations] and express moral condemnation when their pleas go unheeded; they formulate codes of ethics and endow them with sufficient legitimacy to ensure that flagrant violators lose standing in the relevant community.

Domestic NGOs, we argue, operate similarly.

As global institutions constitute domestic NGOs and confer authority and legitimacy on them, nation-states may find themselves increasingly prodded toward reform from both above and below (also see Schofer and Hironaka, 2005). It is easy to imagine a future in which the role of domestic NGOs in the theater of democracy is even more commanding, with even more environmental policies appearing to result from domestic pressures. In our vision, global dynamics both construct domestic NGOs and authorize and legitimate their 'influence' over nation-states. ${ }^{33}$

\section{CONCLUSION}

In this article, our agenda has been threefold. We have sought to rethink the role of domestic environmental NGOs in the policy reform process, to call attention to the embedding of both NGOs and policies in a wider world society, and thus to reconsider the overall environmentalization of nation-states. In the Asian context, the orthodox account - leading from local environmental degradation to grassroots organizing to regulatory change and finally to environmental improvement proves unconvincing. None of the main causal connections is borne out empirically, including the one that is the focus of this article. The conventional account's basic assumptions about domestic NGOs seem implausible. At close range, domestic NGOs appear to be derivative rather than autonomous and busy rather than effective. Indeed, our quantitative event-history analyses find that INGO chapters, especially environmental ones, are the principal drivers of national policy reform.

For some social scientists, including many western social movement scholars, the NGO-to-reform causal chain elicits almost religious-like devotion. It draws heavily on scripts of modernity that are deeply institutionalized in world society, which depict a rationalized universe in which humans are conceived to be autonomous actors with natural capacities to organize and to pursue and defend their clear-cut interests. The account enjoys utmost legitimacy.

Regardless, then, whether the standard view explains the empirical world, it nevertheless embodies main themes of a broader global-institutional scheme that celebrates participatory democracy and constitutes democratic participants. In the end, this is why the NGO policy story prevails. Domestic NGOs flourish as part of a global institutional system that sponsors the theater of democracy, even 
as the substantive impact of NGOs remains only loosely coupled to measurable social change.

\section{ACKNOWLEDGEMENTS}

Work on this article was supported by a grant from the Consortium on Law and Values in Health, Environment, and Life Sciences and a GRPP grant from the University of Minnesota and also a grant from the Newkirk Center for Science and Society at the University of California, Irvine. We appreciate the helpful comments and suggestions we received from Ann Hironaka, Frank Lechner, John W. Meyer, Yong-Suk Jang, Gil-Sung Park, and participants in both Korea University's Conference on Development and Challenges of Globalization and the University of Minnesota's Globalization Workshop.

\section{NOTES}

1 See [http://www.bicusa.org/bicusa/issues/about_the_bank_information_center/index. php]. For a general discussion and empirical look at the origins of civil society, see Schofer and Longhofer (2006).

2 Sonnenfeld and Mol (2006) document trends in environmental performance and reform in 11 Asian countries. They argue that patterns of development and ecological disruption in Asia share many characteristics with those observed in OECD countries during their own industrial and economic takeoffs.

3 See [http://www.china.org.cn/english/scitech/149641.htm].

4 See [http://www.unep.org/geo2000/english/0164.htm].

5 See [http://www.cfr.org/publication.html?id=7391].

6 In less democratized countries, civil society may be dominated by quasi-state bodies, such as officially licensed NGOs (see, for example, Gordon, 1998; Liu, 2006). Conceptually and practically, such entities close much of the distance between governmental and nongovernmental organizations ( $\mathrm{Wu}, 2003)$.

7 See [http://www.savetherhino.org/php/press.php?id=434\&item $=570]$.

8 See [http://www.hrw.org/worldreport3/Asia.htm].

9 See [http://www.unep.org/geo2000/english/0164.htm].

10 See [http://www.einap.org/jec/apnec2_d_e.html].

11 See [http://www.mekongwatch.org/english/policy/].

12 See [http://www.ngoforum.org.kh/Core/annual_report_2000.htm].

13 See [http://www.mofa.go.jp/region/asia-paci/spf/palm2003/outcome-1.html].

14 See [http://www.gdrc.org/ngo/jpngo-face.html].

15 For example, India's Environmental Law Institute aims to 'build the capacity of Indian civil society and enforcement agencies for sound environmental decisionmaking' [http://www2.eli.org/research/india.htm].

16 Thus one analyst of Asian NGOs observes: 'If the state views the [NGO] sector with suspicion and does not wish to permit either social service delivery or advocacy organizations to exist, then the legal environment within which they operate is not an "enabling" one. The state imposes controls that prevent associations and foundations from coming easily into existence, and it watches closely what those organizations is does permit to exist actually do' (Simon, 2006).

17 See [http://www.ejustice.lk/]. 
18 See [http://www.bicusa.org/bicusa/issues/about_the_bank_information_center/index. php]. Literally hundreds of activist toolkits - local, national, and global - can be found on the Internet, demonstrating the extraordinary degree to which activism is routinized and institutionalized in the world polity.

19 According to one recent survey, 70 percent of the funding for Ugandan NGOs comes from international donors, and much of the rest comes from the state (which is itself the beneficiary of international aid) (Barr et al., 2005). Much the same holds true for NGOs in Thailand (Pongsapich, 1997).

20 Large numbers of environmental INGOs were also founded around the times of these two conferences. See the figure in Frank et al. (1999: 85).

21 Empirical research suggests that wealth, democracy, and education are more important to early adopters of environmental protection in the West, while connections to world society are more important to later adopters elsewhere (Longhofer and Schofer, 2006). Tolbert and Zucker describe the general process (1983). Features of both nation-states and the world are clearly involved, though it is well to remember that nation-states themselves are the creatures of world society (Meyer et al., 1997a).

22 See [http://www.jacses.org/en/about_jacses/profile01.html].

23 Frank and McEneaney (1999) show this two-way relationship vis-à-vis the lesbian and gay social movement and policies on same-sex sex.

24 The 15 countries are China, India, Indonesia, Japan, Malaysia, Mongolia, Nepal, Singapore, South Korea, Pakistan, Philippines, Sri Lanka, Taiwan, Thailand, and Vietnam. Complete data for Bangladesh, Bhutan, Brunei, Burma, Cambodia, Laos, and North Korea were unavailable.

25 We use both a general measure of INGO chapters and a specific measure of environmental INGO chapters because our data on the former variable covers a longer period of time. The correlation between the two indicators is .75 .

26 Models 1 and 2 analyze policy adoptions in 14 countries: China, India, Indonesia, Japan, Laos, Malaysia, Mongolia, Nepal, Pakistan, Papua New Guinea, Philippines, South Korea, Sri Lanka, and Thailand. In Model 3, $\mathrm{x}$ and $\mathrm{y}$ were dropped due to missing data.

27 India's Environmental Law Institute depicts itself in just these terms. See [http:// www2.eli.org/research/india.htm].

28 See [http://www.unep.org/geo2000/english/0164.htm].

29 See [http://www.ngoforum.org.kh/Core/annual_report_2000.htm].

30 See [http://www.ngoforum.org.kh/Core/annual_report_2000.htm].

31 See [http://www.environmentaldefense.org/documents/4195_International\%20Prog ram $\% 20$ Brochure.pdf].

32 See [http://www.unep.org/geo2000/english/0164.htm]. INGOs also provide directimplementation services. The World Wide Fund for Nature, for example, helps manage 17 of Indonesia's 32 national parks, with US\$5 million and 15 staff (Betsill and Corell, 2001).

33 This imagery provides an alternative to Keck and Sikkink's boomerang effect (1998). They assume the originality and priority of domestic pressures, which are then enhanced by global opportunities and allies.

\section{REFERENCES}

Ascher, W. (1999) Why Governments Waste Natural Resources: Policy Failures in Developing Countries. Baltimore, MD: Johns Hopkins University Press. 
Barr, A., Fafchamps, M. and Owens, T. (2005) 'The Governance of Non-Governmental Organizations in Uganda', World Development 33: 657-79.

Bestill, M.M. and Corell, E. (2001) 'NGO Influence in International Environmental Negotiations: A Framework for Analysis', Global Environmental Politics 1: 65-85.

Boli, J. and Thomas, G.M. (eds) (1999) Constructing World Culture: International Nongovernmental Organizations Since 1875. Stanford, CA: Stanford University Press.

Brechin, S.R. and Kempton, W. (1994) 'Global Environmentalism: A Challenge to the Postmaterialism Thesis?', Social Science Quarterly 75: 245-69.

Broadbent, J. (1998) Environmental Politics in Japan: Networks of Power and Protest. Cambridge: Cambridge University Press.

Bryant, R.L. (2005) Nongovernmental Organizations in Environmental Struggles: Politics and the Making of Moral Capital in the Philippines. New Haven, CT: Yale University Press.

California Institute of Public Affairs (2005) The World Directory of Environmental Organizations Online, available online at: [http://www.interenvironment.org/wd/], accessed 18 May 2005.

Carr, S. and Mpande, R. (1996) 'Does the Definition of the Issue Matter? NGO Influence and the International Convention to Combat Desertification in Africa', Journal of Commonwealth and Comparative Politics 34: 143-66.

Center for International Comparisons at the University of Pennsylvania (CICUP) (2002) Penn World Table Version 6.1 [dataset].

Dunlap, R. and Mertig, A. (1997) 'Global Environmental Concern: An Anomaly for Postmaterialism', Social Science Quarterly 78: 24-9.

Frank, D.J. and McEneaney, E.H. (1999) 'The Individualization of Society and the Liberalization of State Policies on Same-Sex Sexual Relations, 1984-1995', Social Forces 77: 911-44.

Frank, D.J., Hironaka, A. and Schofer, E. (2000a) 'The Nation-State and the Natural Environment over the Twentieth Century', American Sociological Review 65: 96-116.

Frank, D.J., Hironaka, A. and Schofer, E. (2000b) 'Environmentalism as a Global Institution', American Sociological Review 65:122-7.

Frank, D.J., Hironaka, A., Meyer, J.W., Schofer, E. and Tuma, N.B. (1999) 'The Rationalization and Organization of Nature in World Culture', in J. Boli and G.M. Thomas (eds) Constructing World Culture: International Nongovernmental Organizations Since 1875, pp. 81-99. Stanford, CA: Stanford University Press.

Gordon, J. (1998) 'NGOs, the Environment, and Political Pluralism in New Order Indonesia', Explorations in Southeast Asian Studies 2: 47-68.

Hironaka,A. (2000) 'The Globalization of Environmental Protection: The Case of Environmental Impact Assessment', International Journal of Comparative Sociology 43: 65-78.

Hironaka, A. and Schofer, E. (2002) 'Decoupling in the Environmental Arena: The Case of Environmental Impact Assessments', in A. Hoffman and M. Ventresca (eds) Organizations, Policy and the Natural Environment: Institutional and Strategic Perspectives, pp. 214-31. Stanford, CA: Stanford University Press.

Jasanoff, S. (1997) 'NGOs and the Environment: From Knowledge to Action', Third World Quarterly 18: 579-94.

Keck, M.E. and Sikkink, K. (1998) Activists Beyond Borders:Advocacy Networks in International Politics. Ithaca, NY: Cornell University Press.

Liu, D. (2006) 'How World Conferences Matter: International Political Participation and Changes in the Chinese and the Indian Women's Movements', unpublished doctoral thesis, Department of Sociology, Harvard University. 
Longhofer, W. and Schofer, E. (2006) 'The Domestic and Global Origins of Environmental Association', working paper, Department of Sociology, University of Minnesota.

Marshall, M.G. and Jaggers, K. (2000) Polity IV: Political Regime Characteristics and Transitions, 1800-1999 [dataset]. College Park, MD: Center for International Development and Conflict Management, University of Maryland.

Meyer, J.W., Boli, J., Thomas, G.M. and Ramirez, F.O. (1997a) 'World Society and the Nation-State', American Journal of Sociology 103: 144-81.

Meyer, J.W., Frank, D.J., Hironaka, A., Schofer, E. and Tuma, N.B. (1997b) 'The Structuring of a World Environmental Regime, 1870-1990', International Organization 51: 623-51.

Pednekar, S.S. (1995) 'NGOs and Natural Resource Management in Mainland Southeast Asia', TDRI Quarterly Review 10: 21-7.

Pongsapich, A. (1997) 'Thailand', in L.M. Salamon and H.K. Anheier (eds) Defining the Nonprofit Sector: A Cross-National Analysis, pp. 446-68. Manchester: Manchester University Press.

Potter, D. (ed.) (1996) NGOs and Environmental Policies: Asia and Africa. London: Frank Cass.

Princen, T. (1994) 'NGOs: Creating a Niche in Environmental Diplomacy', in T. Princen and M. Finger (eds) Environmental NGOs in World Politics: Linking the Local and the Global, pp. 29-47. London: Routledge.

Rock, M.T. and Angel, D.P. (2005) Industrial Transformation in the Developing World. Oxford: Oxford University Press.

Schofer, E. (2003) 'The Global Institutionalization of Geological Science', American Sociological Review 68(5): 730-59.

Schofer, E. and Hironaka, A. (2005) 'The Effects of World Society on Environmental Protection Outcomes', Social Forces 84: 25-47.

Schofer, E. and Longhofer, W. (2006) 'The Structural Sources of Associational Life', working paper, Department of Sociology, University of Minnesota.

Simon, K.W. (2006) 'NGO Regulations in East and Southeast Asia: A Comparative Perspective', Thailand Law Forum, available online at: [<http://members.tripod.com/ asialaw/articles/ngo.html $>$.

Sonnenfeld, D.A. (2002) 'Social Movements and Ecological Modernization: The Transformation of Pulp and Paper Manufacturing', Development and Change 33:1-27.

Sonnenfeld, D.A. and Mol, A.P.J. (2006) 'Environmental Reform in Asia: Comparisons, Challenges, Next Steps', Journal of Environment and Development 15: 112-37.

Tolbert, P.S. and Zucker, L.G. (1983) 'Institutional Sources of Change in the Formal Structure of Organizations: The Diffusion of Civil Service Reform, 1880-1935', Administrative Science Quarterly 28: 22-39.

Union of International Associations (UIA) (1948-99) Yearbook of International Organizations. Munich: K.G. Saur.

Wapner, P. (1996) Environmental Activism and World Civic Politics. Albany: SUNY Press.

Wong, A. (2001) The Roots of Japan's Environmental Policies. New York: Garland.

World Bank (2001) World Development Indicators 2001. Washington, DC: World Bank.

World Wide Fund for Nature (WWF) (2002) Living Planet Report 2002. Gland, Switzerland: World Wide Fund for Nature.

Wu, F. (2003) 'Democratization and Civil Society in East Asia: Environmental GONGO Autonomy: Unintended Consequences of State Strategies in China', Good Society 12: $35-45$. 
York, R., Rosa, E.A. and Dietz, T. (2003) 'Footprints on the Earth: Environmental Consequences of Modernity', American Sociological Review 68(2): 279-300.

David John Frank is Associate Professor of Sociology at the University of California, Irvine. His interests center on world society and global institutions, especially in the realms of environmental protection, higher education, criminal sex laws, and personhood. His most recent work includes a 2006 book from Stanford University Press, entitled Reconstructing the University: Worldwide Shifts in Academia in the 20th Century (with Jay Gabler), and an article under review at Theory and Society, called 'The University: Worldwide Expansion and Change' (with John W. Meyer). Address: Department of Sociology, University of California, Irvine, 4107 Social Science Plaza, Irvine, CA 92697, USA. [email: frankd@uci.edu]

Wesley Longhofer is a doctoral student in the Department of Sociology at the University of Minnesota. His research focuses on voluntary associations and environmental movements in comparative perspective. He is currently working on a project examining the relationships between world society, civic engagement, and development in Bangalore, India. Address: Department of Sociology, University of Minnesota, 909 Social Sciences, 267 19th Ave. South, Minneapolis, MN 55455, USA. [email: long0324@umn.edu]

Evan Schofer is an Associate Professor of Sociology at the University of Minnesota. His cross-national studies of civil society, science, and educational systems have appeared in the American Sociological Review, Social Forces, and in a co-authored book entitled Science in the Modern World Polity: Globalization and Institutionalization (Stanford University Press, 2003). His ongoing research examines civil society in comparative context. $\mathrm{He}$ is also engaged in a new project examining variation in national education systems and consequences for economic inequality. Address: Department of Sociology, University of Minnesota, 909 Social Sciences, 267 19th Ave. South, Minneapolis, MN 55455, USA. [email: schofer@soc.umn.edu] 
